\title{
Uprawnienie pracodawcy do kontroli trzeźwości pracowników
}

\section{The employer's right to control the sobriety of employees}

\author{
dr Janusz Żołyński \\ ORCID 0000-0001-7376-1693
}

\begin{abstract}
Streszczenie Zapewnienie bezpiecznego świadczenia pracy należy do podstawowych obowiązków pracodawcy. Przejawem tego obowiązku jest zakaz dopuszczenia do pracy pracownika pod wpływem alkoholu, po uprzedniej kontroli trzeźwości. Zdaniem autora podstawę przeprowadzania kontroli trzeźwości pracownika należy wywodzić z ogólnej zasady prawa pracy, nakazującej pracodawcy w sposób bezwzględny zapewnienie pracownikom bezpiecznych i higienicznych warunków pracy. Uprawnienie pracodawcy wynika bowiem z obowiązku ochrony najwyższego dobra dla człowieka, jakim poza godnością jest jego życie i zdrowie.
\end{abstract}

Słowa kluczowe: alkohol, ochrona danych osobowych, godność, życie i zdrowie.

Summary Ensuring the safe performance of work is one of the fundamental employer's obligation which manifests itself in prohibiting an employee, being under the influence of alcohol, from admittance to work upon prior sobriety control. The grounds for carrying out that control is to be derived from a general labour law principle demanding from the employer to ensure healthy and safe working conditions for employees. The employer's right arises from the obligation to protect the superior personal right which is, apart from the dignity, the life and health.

Keywords: alcohol, protection of personal data, dignity, life and health.

JEL: K31

Str. 34-38

\section{Bibliografia}

Banaszak, B. (2002). Ogólne wiadomości o prawach człowieka. W: B. Banaszak, A. Preisner (red.). Prawa $i$ wolności obywatelskie w Konstytucji RP. Warszawa.

Cieśliński, A. (2003). Wspólnotowe prawo gospodarcze. Warszawa.

Jaśkowski, K. (2007). Porozumienia zbiorowe w prawie pracy. W: L. Florek (red.), Indywidualne a zbiorowe prawo pracy. Warszawa.

Kużniar, R. (2000). Prawa człowieka. Prawo, instytucje, stosunki międzynarodowe. Warszawa.

Kwoka, K. (2019). Wyrywkowe kontrole trzeźwości na bakier z prawem. Rzeczpospolita z 9 maja 2019 r., D 1.

Nowak, M. (1993). Trzy generacje praw człowieka. Ich znaczenie w świetle przesłanek ideowych i historycznych oraz w świetle ich genezy. W: B. Banaszak (red.), Prawa czlowieka. Geneza, koncepcje, ochrona. Wrocław.

Piechowiak, M. (1999). Filozofia praw człowieka. Prawa człowie- ka wświetle ich międzynarodowej ochrony. Lublin 1999.

Plis, J. (2014). Wrowadzenie do problematyki koncepcji praw czlowieka trzeciej generacji Karela Vasaka, https://repozytorium.ur.edu.pl/bitstream/handle/item/825/Plis\%20-\%20fin. pdf?sequence=1\&isAllowed=y (9.05.2019).

Sanetra, W. (2006). O roli Sądu Najwyższego w zapewnianiu zgodności z prawem oraz jednolitości orzecznictwa sądowego. Przegląd Sądowy, (9).

Tomza, A. (2010). Teoria wykładni prawa Jerzego Wróblewskiego a dyrektywalna koncepcja znaczenia Kazimierza Ajdukiewicza. Studia Prawno-Ekonomiczne, LXXXII.

Zieliński, M., Bogucki, O., Choduń, A., Czepita, S., Kanarek, B., Municzewski, A. (2009). Zintegrowanie polskich koncepcji wykładni prawa. Ruch Prawniczy, Ekonomiczny i Socjologiczny, (4).

Żołyński, J. (2014). Glosa do wyroku SN z dnia 4 września 2013 r., sygn. akt II PK 358/12 w sprawie dopuszczalności zawierania więcej niż jednej umowy o pracę na okres próbny z tym samym pracodawcą. Praca i Zabezpieczenie Społeczne, (3).

Żołyński, J. (2016). Aksjologiczne, normatywne i społeczne pod- stawy prawa rozwiązwania sporów zbiorowych pracy. Gdańsk. 
